\title{
Assessment of Surface Water Quality of King Abdullah Canal, Using Physico-Chemical Characteristics and Water Quality Index, Jordan
}

\author{
Atef Faleh Al-Mashagbah \\ Institute of Earth and Environmental Sciences, Al al-Bayt University, Al-Mafraq, Jordan \\ Email: Atef.mashagbah@yahoo.com
}

Received 25 February 2015; accepted 12 March 2015; published 13 March 2015

Copyright (C) 2015 by author and Scientific Research Publishing Inc.

This work is licensed under the Creative Commons Attribution International License (CC BY).

http://creativecommons.org/licenses/by/4.0/

(c) (i) Open Access

\begin{abstract}
The main aim of this research is to evaluate the water quality of King Abdullah Canal (KAC) using the water quality index method (WQI). For this purpose, nine different sampling sites were used in the calculation of WQI during the period of January to December 2012. The samples were analyzed for various physico-chemical parameters such as $\mathbf{p H}$, electrical conductivity, total suspended solids, ions of Sodium, Potassium, Calcium, Magnesium, Fluorite, Chloride, Sulfate, Bicarbonate, and Nitrate in different seasons (winter, spring, summer and autumn). The analyzed results (by WQI method) have been used to suggest models for predicting water quality. The relative weight assigned to each parameter has a range from 1 to 5 , based on the important parameters for drinking purposes. The computed WQI for the nine samples has a range from 46.66 to 542.08 . The analysis reveals that the water quality status of the study area is varying from excellent to good in the upper part of the canal and from poor to very poor in the lower part of the canal. Comparing with the World Health Organization (WHO) and Jordan Standard (JS), the results indicate that the lower part of the canal is polluted. Therefore, the water is not safe for domestic use and needs further treatment, especially in the lower part of the canal.
\end{abstract}

\section{Keywords}

Water Quality Index, King Abdullah Canal, Physico-Chemical Characteristics, Jordan

\section{Introduction}

Clean water is an essential factor for the human survival and for the whole life. Due to many factors such as the 
population increase, the demand on water is increasing steadily over time. This challenge is leading to more demands for the clean water and therefore the lack of water in many parts of the world is increasing consequently [1]. Human health, on the other hand, is also affected by water, since the agricultural activities depend on water for irrigation [2]. According to a study conducted by the WHO organization, the majority of the diseases in human beings are water produced [3]. Due to these factors, it is necessary to monitor the quality of water and to protect it from pollutions. Water quality is usually calculated by the water quality index. Water quality index is a number that has a finite scale to differentiate between polluted water and very clean water. This number converts different water quality data into one simple indicator that can be used to describe the overall quality of water. WQI is very useful since it can be used by the policy makers to increase the water quality [1] [3]. Thus, it becomes an important factor for the assessment of water quality programs.

The aim of this research is to evaluate the water quality in the KAC, and to provide information on the water parameters of the canal. Furthermore, the water suitability for human use based on computed water quality index values is discussed.

\section{Methodology}

\subsection{Study Area Characteristics}

The study area extends along King Abdullah Canal from the Yarmouk River in the north, to Deir Alla in the south, at an elevation of $235 \mathrm{~m}$ below sea level.

The King Abdullah Canal is the most important water supply for drinking and agricultural in Jordan [4]. The canal extends from the Syrian border in the north down to the Dead Sea in the south (Figure 1). The length of the canal is about $110 \mathrm{~km}$ with a head discharge capacity of $20 \mathrm{~m}^{3} / \mathrm{s}$, and a tail discharge of $6 \mathrm{~m}^{3} / \mathrm{s}$ and constitutes the main valley conveyance structure [4].

Currently, $45 \mathrm{MCM} /$ year of water are pumped from the canal to Zai treatment plant then pumped to Amman. This amount of water is planned to be increased in the future. The concrete canal has a width of 3 meter and a width that varies from 10 to 11 meters. The slope of the canal is about 0.00018 and its capacity is $20 \mathrm{~m}^{3} / \mathrm{s}, \mathrm{re}-$ ducing to $2.3 \mathrm{~m}^{3} / \mathrm{s}$ in the south [4].

\subsection{Sampling Sites and Water Quality Monitoring Station}

The current study describes the application of the Water Quality Index (WQI) to study the changes in water quality at nine sites within King Abdullah Canal and Jordan River, Jordan.

\subsection{Data Availability}

The water quality data were chosen for this study with nine sampling according to the water quality data obtained from the Royal Scientific Society (RSS).

The requisite data of various water quality parameters (based on monthly analysis) were obtained from RSS between January 2012 and December 2012.

\section{Data Analysis}

There are many parameters affect the quality of the water. Therefore, the assessment of surface water quality is a very challenging process. It is difficult to evaluate water quality from a large number of samples, because each sample contains concentrations for many parameters. Depending on the availability of data, analysis has been carried out using Water Quality Index for spatial variation [5]. The explanation below describes the data analysis that was carried out to calculate Water Quality Index.

Surface water samples of nine different locations of the King Abdullah Canal and Jordan River were collected spreading over a period of one year. The water samples were analyzed for different parameters to study the seasonal variations of these parameters according to standard methods. Samples were collected in four seasons' winter, spring, summer and autumn season. Each of the surface water samples was analyzed for 12 parameters such as pH, electrical conductivity, total suspended solids, bicarbonate, chloride, sulphate, nitrate, fluoride, calcium, magnesium, sodium and potassium.

The mean, minimum and maximum values of different selected physic-chemical parameters of 9 surface water samples of the study area for 12 months are shown in Table 1, while the sampling locations are arranged in Table 2 . 


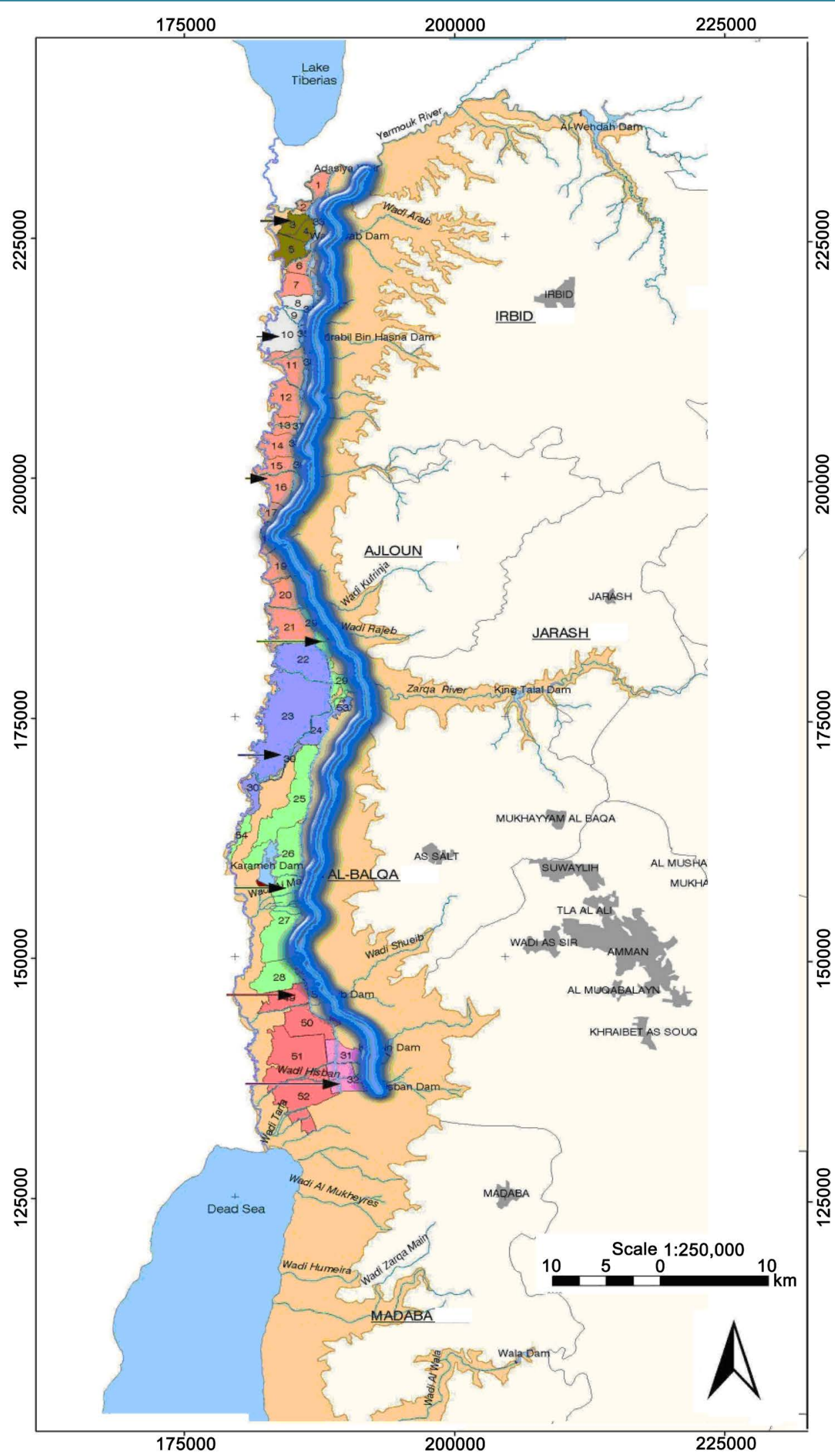

Figure 1. Location of the King Abdullah Canal. 
Table 1. Water quality parameters used in this study, data represented as mean, minimum and maximum values, during twelve months (2012).

\begin{tabular}{|c|c|c|c|c|c|c|c|c|c|c|c|c|}
\hline \multirow{2}{*}{ Parameter } & \multicolumn{9}{|c|}{ Sampling points } & \multirow[b]{2}{*}{ mean } & \multirow[b]{2}{*}{$\min$} & \multirow[b]{2}{*}{$\max$} \\
\hline & JV1 & JV4 & JV6 & JV7 & $\mathrm{C} 2$ & $\mathrm{CX}$ & JR1 & JR2 & JR3 & & & \\
\hline $\mathrm{pH}$ & 8.30 & 8.32 & 8.19 & 8.09 & 8.53 & 8.49 & 7.85 & 7.82 & 7.89 & 8.2 & 7.53 & 8.79 \\
\hline $\mathrm{EC}$ & 992 & 1143 & 1036.4 & 1057 & 2029.4 & 2083.5 & 11427 & 5825.5 & 11290 & 4098 & 585 & 17450 \\
\hline TSS & 41.00 & 7.96 & 33.00 & 47.36 & 83.71 & 66.75 & 430.27 & 124.4 & 371.82 & 134.0 & 2.00 & 1518 \\
\hline $\mathrm{NO}_{3}-\mathrm{N}$ & 1.10 & 0.23 & 0.63 & 0.63 & 7.36 & 7.29 & 6.92 & 2.13 & 5.41 & 3.5 & 0.23 & 12.70 \\
\hline $\mathrm{HCO}_{3}$ & 286.0 & 126.7 & 206.0 & 205.6 & 291.1 & 293.0 & 437.27 & 384.1 & 444.45 & 297.1 & 114. & 716.00 \\
\hline $\mathrm{Cl}$ & 123.0 & 257.7 & 178.3 & 190.1 & 360.5 & 376.7 & 3304 & 1688.5 & 3188.4 & 1074.2 & 63 & 5528 \\
\hline $\mathrm{Na}$ & 78.00 & 118.0 & 94.12 & 99.61 & 224.9 & 235.3 & 1543.1 & 712.9 & 1528.4 & 514.9 & 42.0 & 2510.0 \\
\hline $\mathrm{Mg}$ & 34.00 & 31.68 & 31.25 & 31.64 & 44.05 & 46.62 & 561.64 & 320.0 & 541.27 & 182.5 & 19.0 & 1181.0 \\
\hline $\mathrm{Ca}$ & 75.00 & 44.13 & 58.14 & 58.12 & 117.3 & 119.4 & 397.55 & 238.4 & 398.36 & 167.4 & 39.2 & 565.00 \\
\hline K & 7.00 & 7.19 & 6.88 & 7.18 & 25.16 & 26.04 & 96.42 & 35.55 & 94.13 & 34.0 & 4.00 & 148.00 \\
\hline F & 0.60 & 0.25 & 0.40 & 0.41 & 0.43 & 0.43 & 1.19 & 0.58 & 1.17 & 0.6 & 0.25 & 1.19 \\
\hline $\mathrm{SO}_{4}$ & 116.00 & 51.70 & 77.40 & 79.00 & 217.00 & 214.00 & 2261.00 & 346.00 & 2256.00 & 624.2 & 51.70 & 2261.00 \\
\hline
\end{tabular}

(All parameters are in $\mathrm{mg} / \mathrm{l}$ except $\mathrm{EC}$ in $\mu \mathrm{s} / \mathrm{cm}$ and $\mathrm{pH}$ in $\mathrm{SU}$ ).

Table 2. Arrangement of sampling site.

\begin{tabular}{ccc}
\hline S. No & Sample code & Site name \\
\hline 1 & JV1 & King Abdullah Canal \\
2 & JV4 & King Abdullah Canal \\
3 & JV6 & King Abdullah Canal \\
4 & JV7 & King Abdullah Canal \\
5 & C2 & King Abdullah Canal \\
6 & CX & King Abdullah Canal \\
7 & JR1 & Jordan River \\
8 & JR2 & Jordan River \\
9 & JR3 & Jordan River \\
\hline
\end{tabular}

\section{Calculation of Water Quality Index}

The WQI was first introduced by Horton in the early 1970s; it is a representation of the mathematical means of calculating a single value from many test results. The resulted index represents the level of water quality in a given water area, such as ponds, lake, river or stream [6] [7].

The objective of water quality index is to change the complexity of the water quality data into information that can be used easily by the public. A single number is not enough to describe all of water quality parameters that are not included in the index. On the other hand, a water quality index based on some very important parameters can provide a single indicator of water quality [8].

The WQI of the KAC is computed from different various physicochemical parameters namely: $\mathrm{pH}$ (Hydrogen ion concentration), EC (Electrical conductivity), TSS (Total Suspended Solids), ions of $\mathrm{Na}^{+}$(Sodium), $\mathrm{K}^{+}$(Potassium), $\mathrm{Ca}^{2+}$ (Calcium), $\mathrm{Mg}^{2+}$ (Magnesium), $\mathrm{F}^{-}$(Fluorite), $\mathrm{Cl}^{-}$(Chloride), $\mathrm{SO}_{4}^{2-}$ (Sulfate), $\mathrm{HCO}_{3}^{-}$(Bicarbonate) and $\mathrm{NO}_{3}^{-}$(Nitrate) in different season (winter, spring, summer and autumn). The WQI was calculated monthly in nine different sampling sites in order to assess the suitability of KAC and Jordan River water body for different purpose. 
For calculating the Water Quality Index (WQI), the method followed by [3] [9]-[11] have been employed. In this method the quality rating scale has been assigned to the parameter which is also weighed according to its influence in the overall water quality.

To compute WQI, four steps are followed (Gebrehiwot et al. (2011)). In the first step, the quality rating scale is assigned to the parameter which is also weighed according to its relative importance in the quality of water for drinking purposes. These weights have a range from 1 to 5 . The greatest weight assigned to parameter that has major importance in water quality assessment, while the smallest weight assigned to that parameter that may not be harmful.

The greatest weight of five has assigned to the parameter nitrate due to its importance in water quality assessment; weight of four has assigned to the parameters $\mathrm{pH}$, Electrical Conductivity, Sulphate and Fluorite; weight of three has assigned to parameters Chloride and Bicarbonate; while weight of two has assigned to the parameters Calcium, Magnesium, Sodium and Total Suspended Solids, based on their importance in the quality of water for drinking purposes [12]. Potassium is assigned the minimum weight of one because it plays a fewer role in the water quality assessment. The standards for drinking water as recommended by Jordanian Standards and guidelines for drinking water quality are given in Table 3.

In the next step, the relative weight $\left(R_{w}\right)$ was calculated using the following Equation (1) [13] [14]

$$
R_{W}=\frac{W_{i}}{\sum_{i=1}^{n} W_{i}}
$$

where $R_{w}$ is the relative weight, $W$ is the assigned weight of each parameter and $n$ is the number of parameters. The relative weight $R_{W}$ values of each parameter are given in Table 3.

In the third step, a quality ranking scale $Q_{i}$ for each water parameter is calculated by dividing its concentration by its standard according to the guidelines of [15] and then multiplied by 100 :

$$
\begin{gathered}
Q_{i}=100 \frac{C_{i}}{S_{i}} \\
Q_{i}=100 \frac{\left(v_{o}-v_{i}\right)}{\left(v_{s}-v_{i}\right)}
\end{gathered}
$$

$v_{o}$ and $v_{i}$ represent the observed and ideal values respectively. $v_{s}$ is the WHO drinking water standard for each chemical parameter according to the guidelines of [16] (Table 3). In most cases $v_{i}$ is equal to zero except in certain parameters such as $\mathrm{pH}$, dissolved oxygen etc.

Table 3. Jordanian Standards (WAJ, 1990), guidelines for drinking water quality WHO (2004), and relative weight of physico-chemical parameters used in this study.

\begin{tabular}{ccccc}
\hline Variables & Unit & Jordanian standards & WHO standards & Weight (Wt) \\
\hline $\mathrm{pH}$ & unit & $6.5-9.0$ & $6.5-8.5$ & 4 \\
$\mathrm{EC}$ & $\mu \mathrm{c} / \mathrm{cm}$ & 700 & $<1400$ & 4 \\
$\mathrm{TSS}$ & $\mathrm{mg} / 1$ & 25 & $25-40$ & 2 \\
$\mathrm{NO}_{3}^{-}$ & $\mathrm{mg} / 1$ & $45-70$ & 50 & 5 \\
$\mathrm{HCO}_{3}^{-}$ & $\mathrm{mg} / 1$ & $100-500$ & $25-350$ & 3 \\
$\mathrm{SO}_{4}^{2-}$ & $\mathrm{mg} / 1$ & $200-500$ & 1.5 & 4 \\
$\mathrm{~F}^{-}$ & $\mathrm{mg} / 1$ & 2 & 250 & 3 \\
$\mathrm{Cl}^{-}$ & $\mathrm{mg} / 1$ & 200 & 2 \\
$\mathrm{Na}^{1+}$ & $\mathrm{mg} / 1$ & $200-500$ & $<125$ & 2 \\
$\mathrm{Mg}^{2+}$ & $\mathrm{mg} / 1$ & $200-400$ & 75 & 2 \\
$\mathrm{Ca}^{2+}$ & $\mathrm{mg} / \mathrm{L}$ & $50-150$ & 12 & 1 \\
$\mathrm{~K}^{+}$ & $\mathrm{mg} / \mathrm{L}$ & $75-200$ & & 3 \\
\hline
\end{tabular}


In the fourth step, the Sub Index SI of $i^{\text {th }}$ parameter is determined in Equation (4) for each chemical parameter, which is then used to calculate the overall Water Quality Index WQI :

$$
S I_{i}=W_{i} \times Q_{i}
$$

Finally, WQI is calculated by adding together each sub index values of each water samples as follows:

$$
\mathrm{WQI}=\sum S I_{i}
$$

The values of WQI are usually classified into five categories excellent water, good water, poor water, very poor water and water unsuitable for drinking purposes [1] [17], as shown in Table 4.

In this study, the range of the computed WQI values is varying from 46.66 to 542.08 and therefore, can be categorized into five types "excellent water" to "water unsuitable for drinking". Table 5 shows the percentage of water samples that falls under different quality.

\section{Results and Discussion}

Table 1 gives the different water parameters that be used in this study, as well as their mean, minimum and maximum values. The weighted values and normalization factors were adapted to local conditions, using a variety of sources from literature (e.g. [3] [9] [10] [18]-[20]). The WQI calculation does not take into account some parameters due to the lack of available field data, so the parameters that have a complete data set were used only.

\subsection{Surface Water Quality Variation}

The variations of the physicochemical characteristics along with WQI of the canal water in the different sites were discussed below. The quality of surface water varies from site to site depending up on surface characteristics. The variations of water quality were discussed below.

\subsubsection{Hydrogen Ion Concentration (pH)}

The hydrogen ion concentration $(\mathrm{pH})$ in water is the measurement of the negative logarithm of the concentration of hydrogen ion. Acidic water has a $\mathrm{pH}$ value less than 7 and basic water have a value greater than 7 . The $\mathrm{pH}$ in study area varies from 7.53 to 8.79 (Table 1) indicates that water is slightly alkaline. $99 \%$ of mean samples were not exceeding the permissible limit prescribed by WHO. The $\mathrm{pH}$ mean value of different samples (8.2) is within the desirable and suitable range. The spatial average variation of $\mathrm{pH}$ over a period of time is shown in Figure 2.

Table 4. Classification of WQI values for human consumption.

\begin{tabular}{ccc}
\hline WQI range & Water type \\
\hline $50.1-100$ & Excellent water \\
$100.1-200$ & Good water \\
$200.1-300$ & Poor water poor water \\
& $>300.1$ & Unfit for drinking \\
\hline
\end{tabular}

Table 5. The proportion of water samples that falls under different Water quality categorization.

\begin{tabular}{ccc}
\hline WQI range & Type of water & Percentage of water samples \\
\hline$<50$ & Excellent water & 11.1 \\
$50.1-100$ & Good water & 33.3 \\
$100.1-200$ & Poor water & 22.2 \\
$200.1-300$ & Very poor water & 11.1 \\
$>300.1$ & Unfit for drinking & 22.2 \\
\hline
\end{tabular}




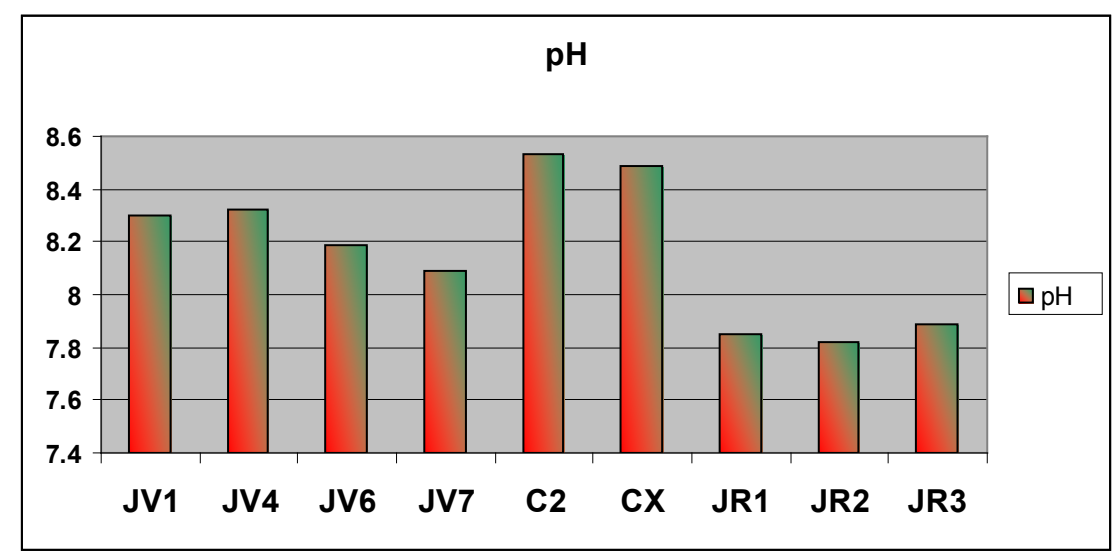

Figure 2. Average $\mathrm{pH}$ values along $\mathrm{KAC}$ and Jordan River.

\subsubsection{Electrical Conductivity}

Electrical conductivity is a measure of the capability of water to carry an electrical current. This capacity is related to the total amount of solids dissolved in the water [21]. Hence water with high ions content tends to have higher conductivity, which is an indicator of high solid concentration dissolved in the water [22].

The values of water conductivity in the canal varied from $585 \mu \mathrm{s} / \mathrm{cm}$ in the upper part of the canal to 17,450 $\mu \mathrm{s} / \mathrm{cm}$ among the stations in the Jordan River. The value of conductivity was recorded lowest in JV1 at KAC and maximum in JR1 at Jordan River, shows poor quality of water according to the classification of WHO. The mean value was $4098 \mu \mathrm{s} . \mathrm{cm}^{-1}$.

The results show that EC values of river water are increasing from upstream towards downstream. Prescribed standard values by WHO for EC is $1400 \mu \mathrm{s} . \mathrm{cm}^{-1}$. The value of EC is very high in Jordan River which exceeded the WHO maximum limit as shown in Figure 3.

\subsubsection{Total Suspended Solids}

Total suspended solids (TSS) in surface water are a result of stream bank, storm water runoff, channel erosion, plankton, dead plant, and re-suspension of sediment into the water column [23]. The surface water's ecosystem is affected negatively by a high concentration of TSS. The suspended solids determination is useful in the analysis of sewage and other waste waters and is as significant as biochemical oxygen demand determination.

In this study, the total suspended solids of river water samples range from $2 \mathrm{mg} / \mathrm{l}$ at $\mathrm{KAC}$ to $1518 \mathrm{mg} / \mathrm{l}$ at $\mathrm{JR}$, with a mean value of $134 \mathrm{mg} / \mathrm{l}$ (Figure 4).

\subsubsection{Bicarbonate}

The amounts of bicarbonate, carbonate, and carbonic acid in water are related to the Hydrogen Ion concentration. In normal surface water where $\mathrm{pH}$ condition is less than 9 , bicarbonate became predominates. Bicarbonate concentrations in natural waters varied from less than $25 \mathrm{mg} / \mathrm{l}$ in non carbonate rocks areas to over $400 \mathrm{mg} / \mathrm{l}$ where carbonate rocks are distribute.

The bicarbonate was found to be the most abundant and varies in concentration from $114 \mathrm{mg} / \mathrm{l}$ in JV4 to 716 $\mathrm{mg} / \mathrm{l}$ in JR3 with an average concentration of $297.1 \mathrm{mg} / \mathrm{l}$.

All the samples of JV were found to be within safe limits of Jordanian Standards while the JR samples were exceeded the JS of 100 to $500 \mathrm{mg} / \mathrm{l}$. A high concentration of bicarbonates in drinking water is deviated by weathering of calcium bearing rocks. Figure 5 shows changes in $\mathrm{HCO}_{3}$ along $\mathrm{KAC}$ and Jordan River

\subsubsection{Nitrate}

Nitrates are a measure of the oxidized form of nitrogen and are a main nutrient in aquatic environments. The nitrate level of the measured samples was low. They fall below the MCL for the JS Drinking water standards and WHO, which was $50 \mathrm{mg} / 1 \mathrm{NO}_{3}$, Nitrate content in river water samples of KAC and JR ranged from $0.23 \mathrm{mg} / \mathrm{l}$ to $12.70 \mathrm{mg} / \mathrm{l}$ with a mean value equal to $3.5 \mathrm{mg} / \mathrm{l}$ (Figure 6). The most important source of nitrate is the biological oxidation of organic nitrogenous materials. Also nitrate may a result of point and non-point sources such as over-application of fertilizer, septic tanks, sewage disposal systems and soil erosion. 


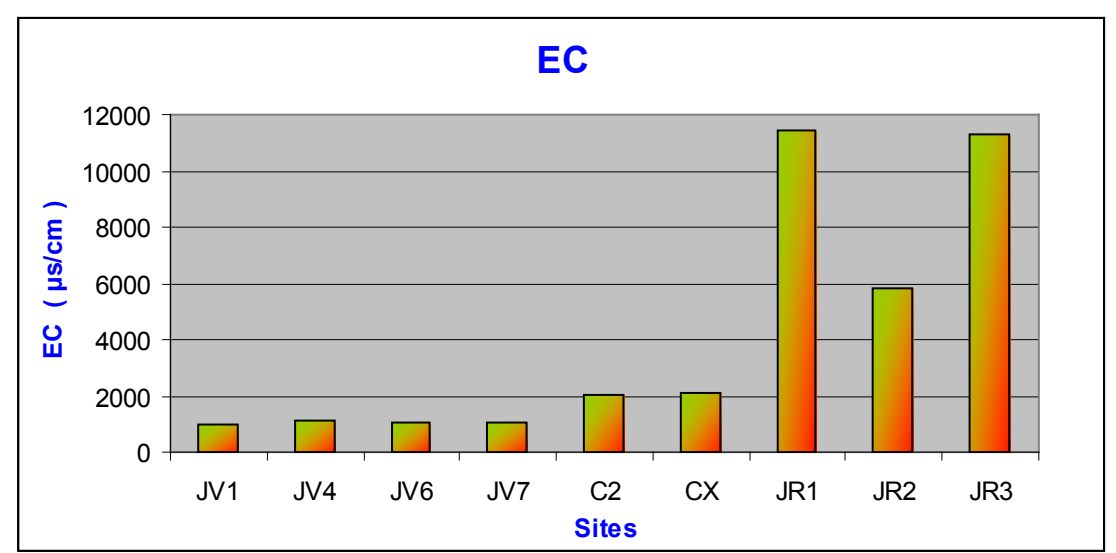

Figure 3. Average EC values along KAC and Jordan River.

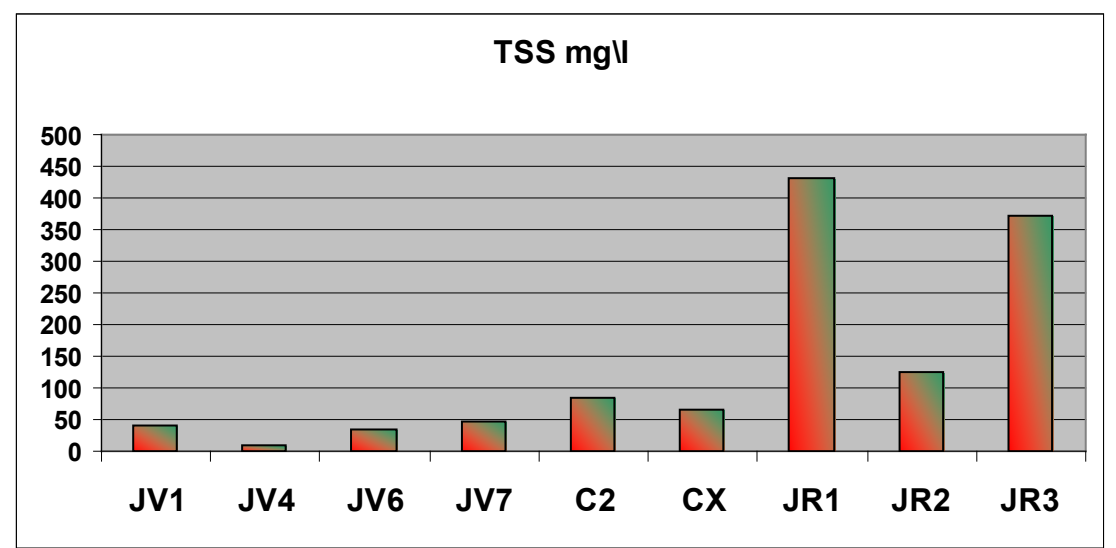

Figure 4. Average TSS values along KAC and Jordan River.

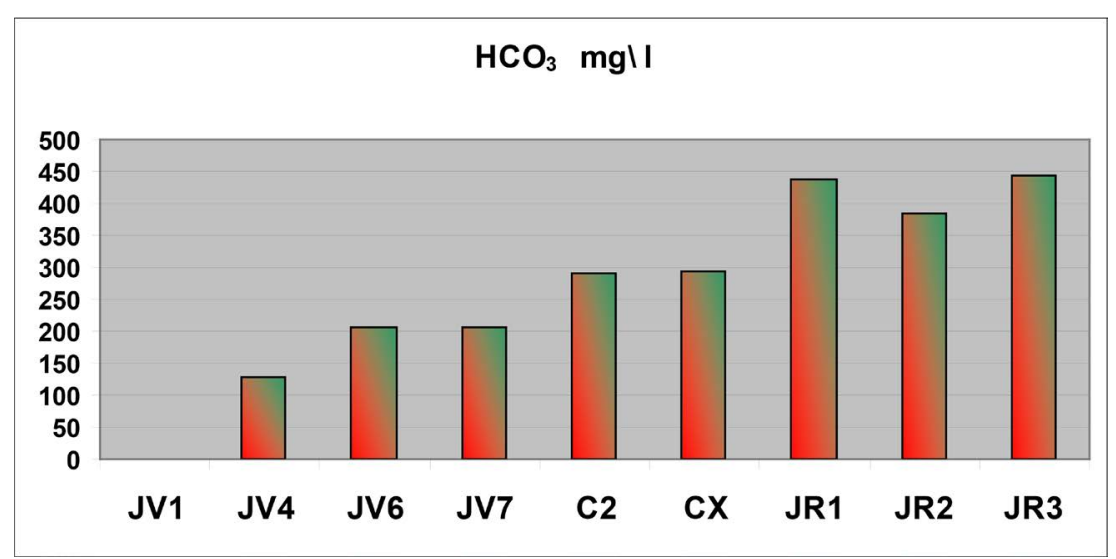

Figure 5. Average $\mathrm{HCO}_{3}$ values along $\mathrm{KAC}$ and Jordan River.

\subsubsection{Chloride}

Chloride is produced from sodium chloride which is dissolved in water from rocks and soil; it is a major component in all types of rocks [24]. High concentration of chloride can make water distasteful and, therefore, unfit for drinking or livestock watering [25]. The chloride reaches the river from different anthropogenic activities like septic tank effluents and animal feeds.

The concentration of chloride was found to be within permissible limits of JS in all sites of KAC except in the JR where a high concentration within the range of 1688.5 to $3304 \mathrm{mg} / \mathrm{l}$ is found. High concentration of chloride 


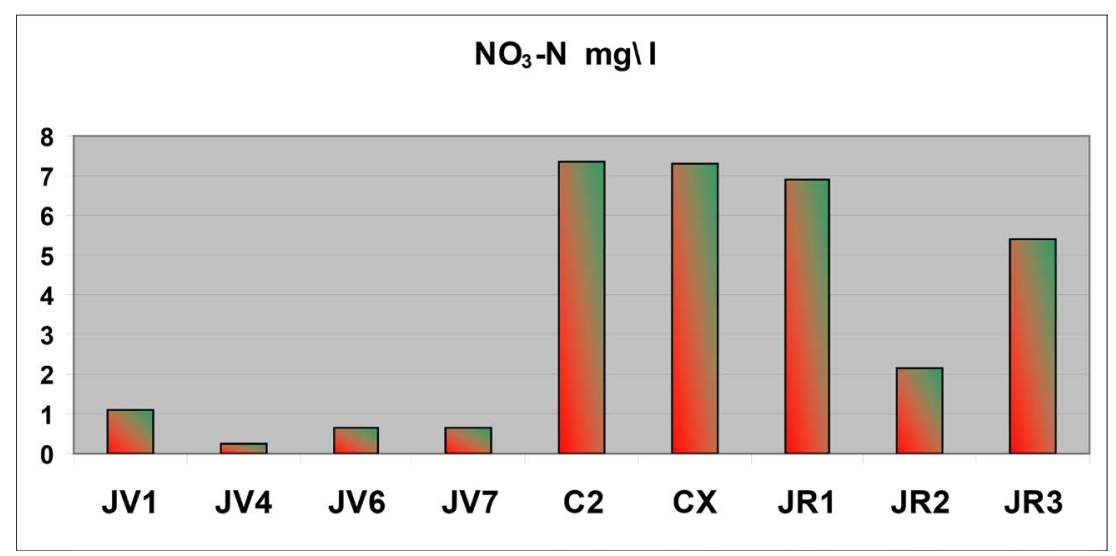

Figure 6. Average $\mathrm{NO}_{3}$ values along $\mathrm{KAC}$ and Jordan River.

cause a salty taste in drinking water and thus water becomes dislikable for drinking. The chloride concentration is an indicator of pollution by sewage. The chloride content was found higher than the prescribed limit for JR (sites JR1, JR2 and JR3)

The variation of chloride over a period of time is shown in Figure 7.

\subsubsection{Sodium}

Sodium is the sixth most abundant element in the Earth's crust and it is produced from rocks and soils. The possible source of sodium concentration in surface water is a result of dissolution of rock salts and weathering of sodium bearing minerals

The concentration of sodium in the study area has a range between $42 \mathrm{mg} / \mathrm{l}$ at KAC to 2510 at JR with an average value of $514.9 \mathrm{mg} / \mathrm{l}$ (Table 1). According to the [16] guideline, the maximum admissible limit is $200 \mathrm{mg} / \mathrm{l}$. In the study area, all the surface water samples in the KAC were found within the maximum permissible limit as far as it is concerned, while all the sample from JR were exceed the maximum permissible limit (Figure 8).

\subsubsection{Magnesium}

Magnesium is a main constituent in natural water and its salts are important contributors to the hardness of water. The magnesium was ranging between 19 to $1181 \mathrm{mg} / \mathrm{l}$ with an average value of $182.5 \mathrm{mg} / \mathrm{l}$.

All the $\mathrm{Mg}^{2+}$ values are within the permissible limit of WHO in KAC, while the value obtained are equally above the permissible limits for JR (Figure 9). The increase in $\mathrm{Mg}^{2+}$ concentration at JR may be due to sewage disposed to that sampling location from Zarqa River.

\subsubsection{Calcium}

Calcium is one of the most common constituents present in natural water. The high concentration of Calcium causes hardness in water and incrustation in boilers.

The calcium concentration was in between 39.2 and $565 \mathrm{mg} / \mathrm{l}$ with an average value of $167.4 \mathrm{mg} / \mathrm{l}$. The increased value of Calcium was found on JR samples due to the mixing with Zarqa river surface water. According to [26] not only the sewage but also the detergents and large scale human use might be the reason of elevation of hardness in water. The average values of calcium are presented in Figure $\mathbf{1 0 .}$

\subsubsection{Potassium}

In the study area, Potassium concentration is varying from 4 to $148 \mathrm{mg} / \mathrm{l}$ with an average value of $34 \mathrm{mg} / \mathrm{l}$; and it was found that four samples had a potassium values within the acceptable limit and five samples above the permissible limit (12 mg/l). Potassium content in the JR water samples found to be higher than the prescribed limit of JS and WHO for drinking purpose (Figure 11).

\subsubsection{Sulphate}

Sulphate is naturally existed in surface water as $\mathrm{SO}_{4}^{2-}$. In our study area, the Sulphate of the surface water samples is varying from 51.7 to $2261 \mathrm{mg} / \mathrm{l}$. The average concentration of the Sulphate value is $624.2 \mathrm{mg} / \mathrm{l} \mathrm{which}$ is 
exceeding the acceptable limit of $250 \mathrm{mg} / \mathrm{l}$ (Figure 12). all the KAC sites are within the permissible limit of JS and WHO Standards, in contrast, all the sample of JR samples exceed the permissible limit which could be due to discharge from waste disposal, domestic waste and untreated sewage [27].

\subsubsection{Fluoride}

Fluoride is a natural contaminant of water. The fluoride in all sites in the study area has a rang from 0.25 to 1.19 $\mathrm{mg} / \mathrm{l}$ (Figure 13), which is within the permissible limit given by WHO and JS (1.5 mg/l).

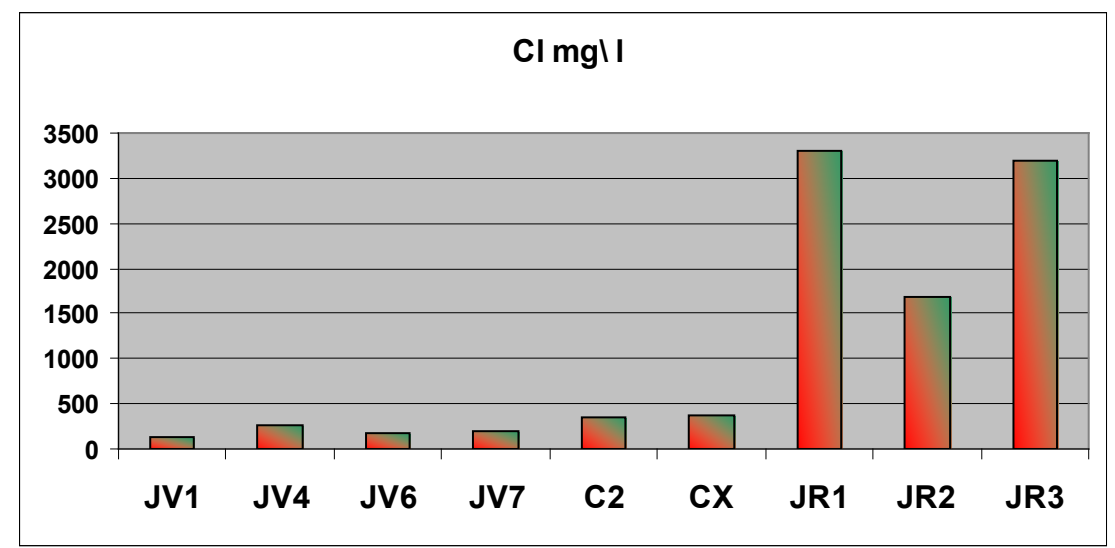

Figure 7. Average $\mathrm{Cl}$ values along $\mathrm{KAC}$ and Jordan River.

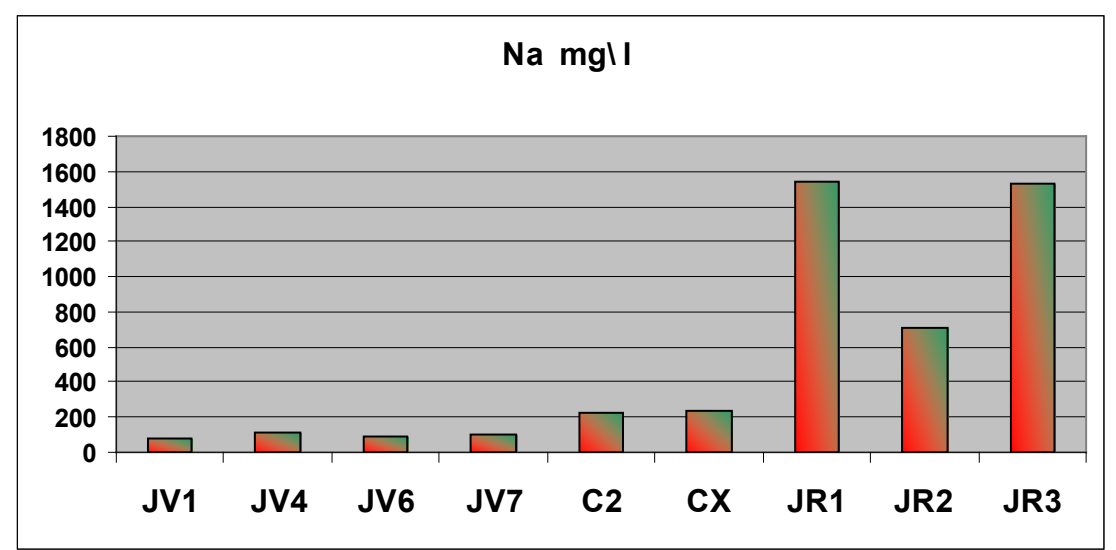

Figure 8. Average Na values along KAC and Jordan River.

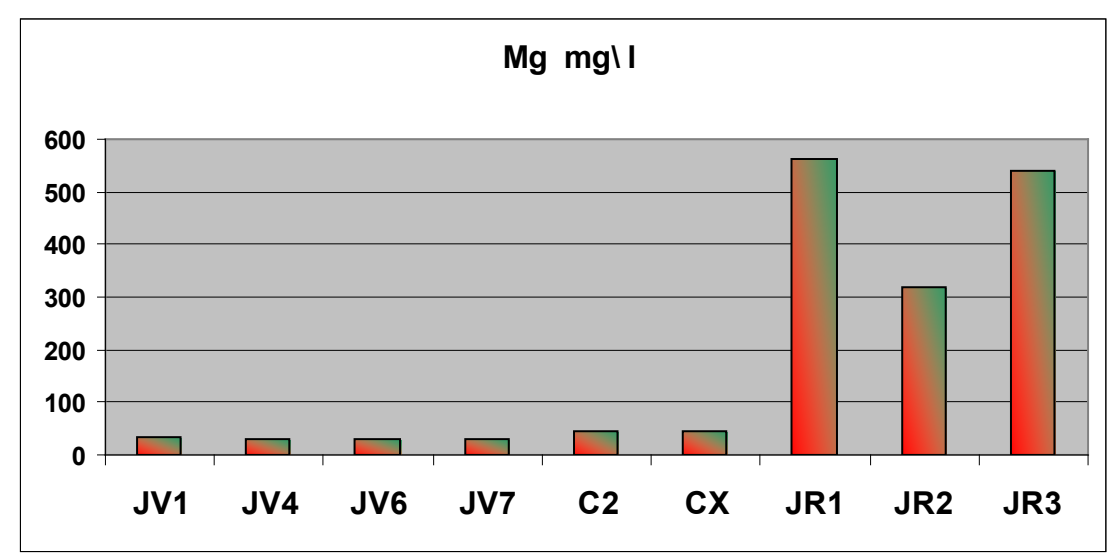

Figure 9. Average $\mathrm{Mg}$ values along $\mathrm{KAC}$ and Jordan River. 


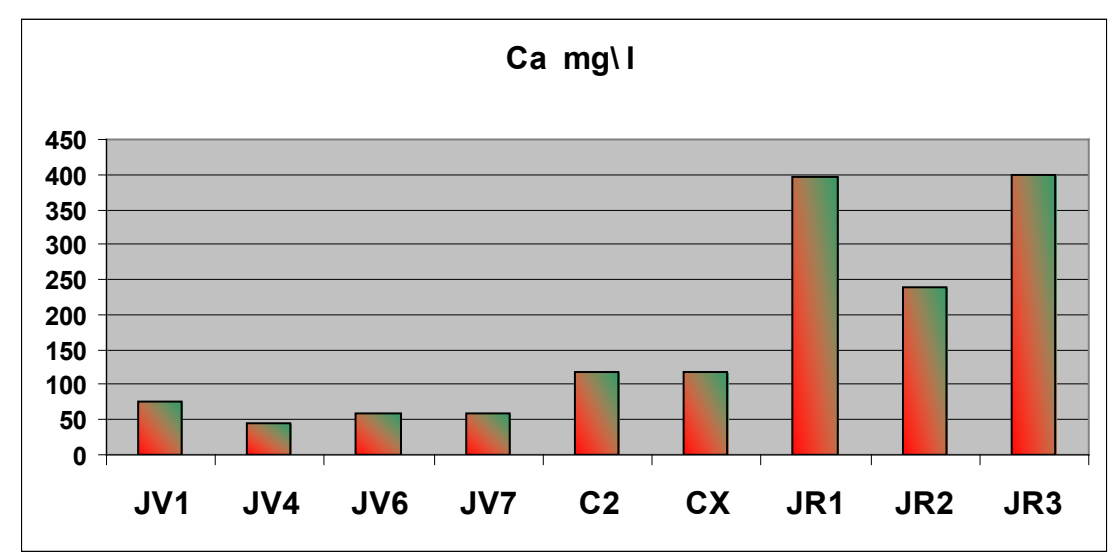

Figure 10. Average Ca values along KAC and Jordan River.

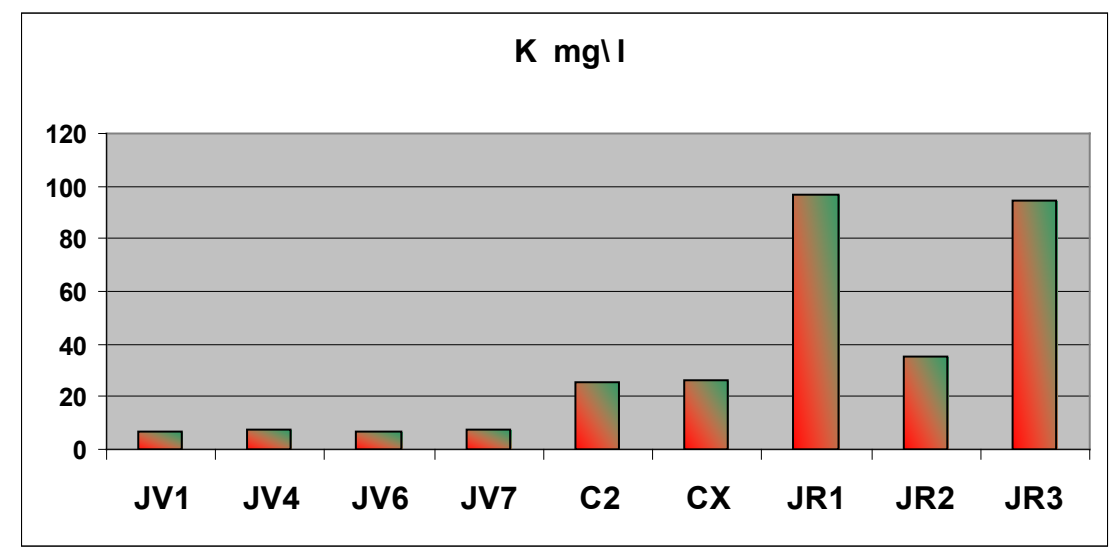

Figure 11. Average K values along KAC and Jordan River.

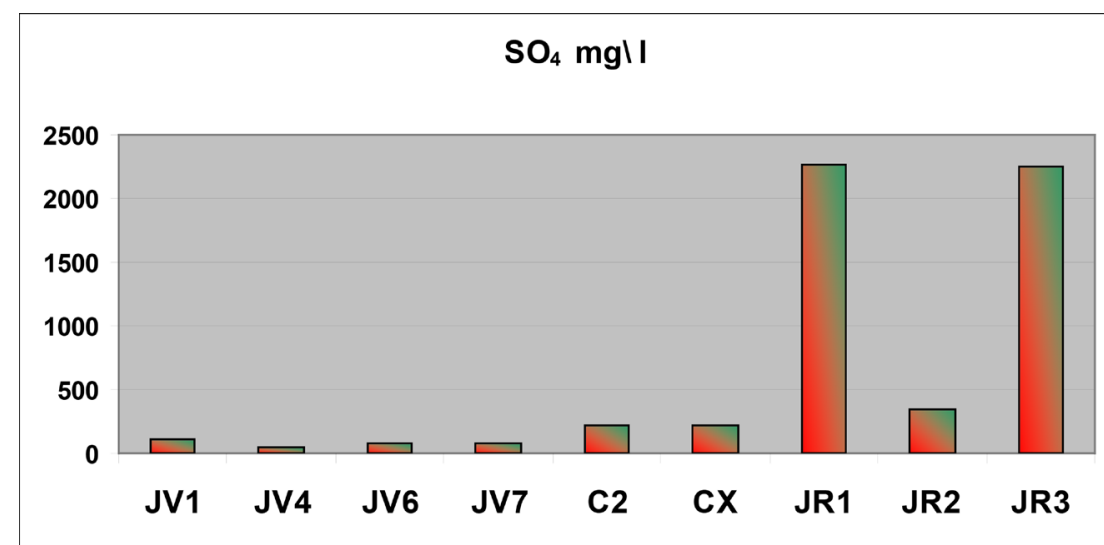

Figure 12. Average $\mathrm{SO}_{4}$ values along $\mathrm{KAC}$ and Jordan River.

\subsection{Water Quality Index Variation}

The average value of twelve physicochemical parameters of KAC and Jordan River were used for calculation of Water Quality Index (WQI) from January to December 2012. The WQI is calculated from different various physicochemical parameters such as $\mathrm{pH}$ (Hydrogen ion concentration), EC (Electrical conductivity), TSS (Total Suspended Solids), ions of $\mathrm{Na}^{+}$(sodium), $\mathrm{K}^{+}$(Potassium), $\mathrm{Ca}^{2+}$ (Calcium), $\mathrm{Mg}^{2+}$ (Magnesium), $\mathrm{NO}_{3}^{-}$(nitrate), $\mathrm{Cl}^{-}$(chloride), $\mathrm{F}^{-}$(Fluorite), $\mathrm{HCO}_{3}^{-}$(Bicarbonate) and $\mathrm{SO}_{4}^{2-}$ (sulfate), in different season (winter, spring, summer, and autumn). Nine different sampling sites were used in the calculation of WQI in order to assess the 
suitability of the water bodies for different drinking purpose.

In this study, the calculated WQI values have a range from 46.66 to 542.08 and thus can be categorized into five water types, excellent water to unsuitable water for drinking". Table 5 shows the percentage of water samples that falls under different quality. Minimum is 46.66 at site JV4 while maximum value was 542.08 at site JR1. Only one single site's water quality can be expressed as excellent (JV4). Water quality of site JV1, JV6 and JV7 can be classified as good water.

The WQI value between 200.1 and 300 indicates the water quality is poor water. In which two stations are under this type, they are site C2 and CX. Site JR2 is classified as a very poor water quality. However, all of these sites can be used for domestic purpose by taking suitable disinfection procedure.

The WQI value greater than 300 indicates that the water quality is unfit for drinking purpose. There are two sites under this type; they are sites JR1 and JR3. The WQI values for various water sampling locations are shown in Table 6 and Figure 14. The percentage of each category is shown in Figure 15.

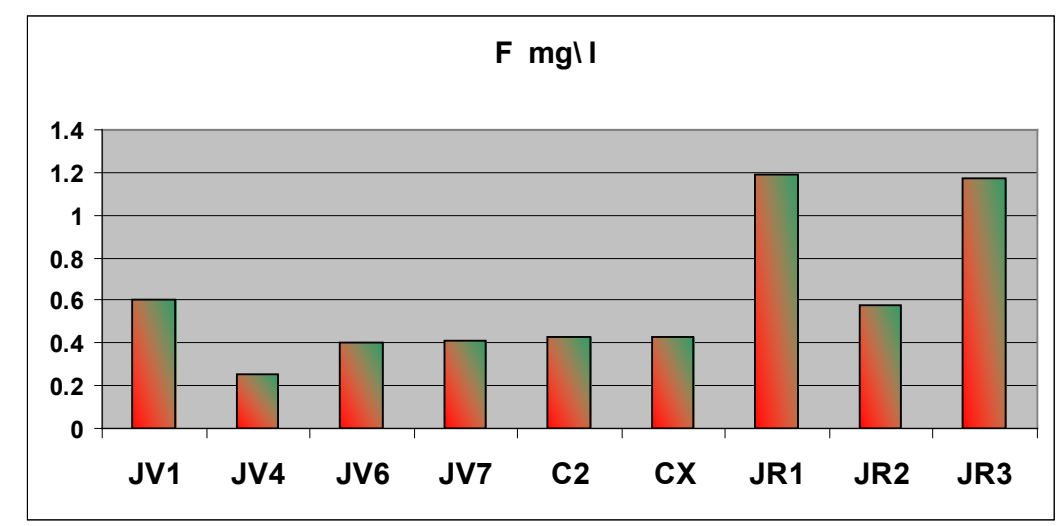

Figure 13. Average F values along KAC and Jordan River.

Table 6. WQI values for KAC AND JR.

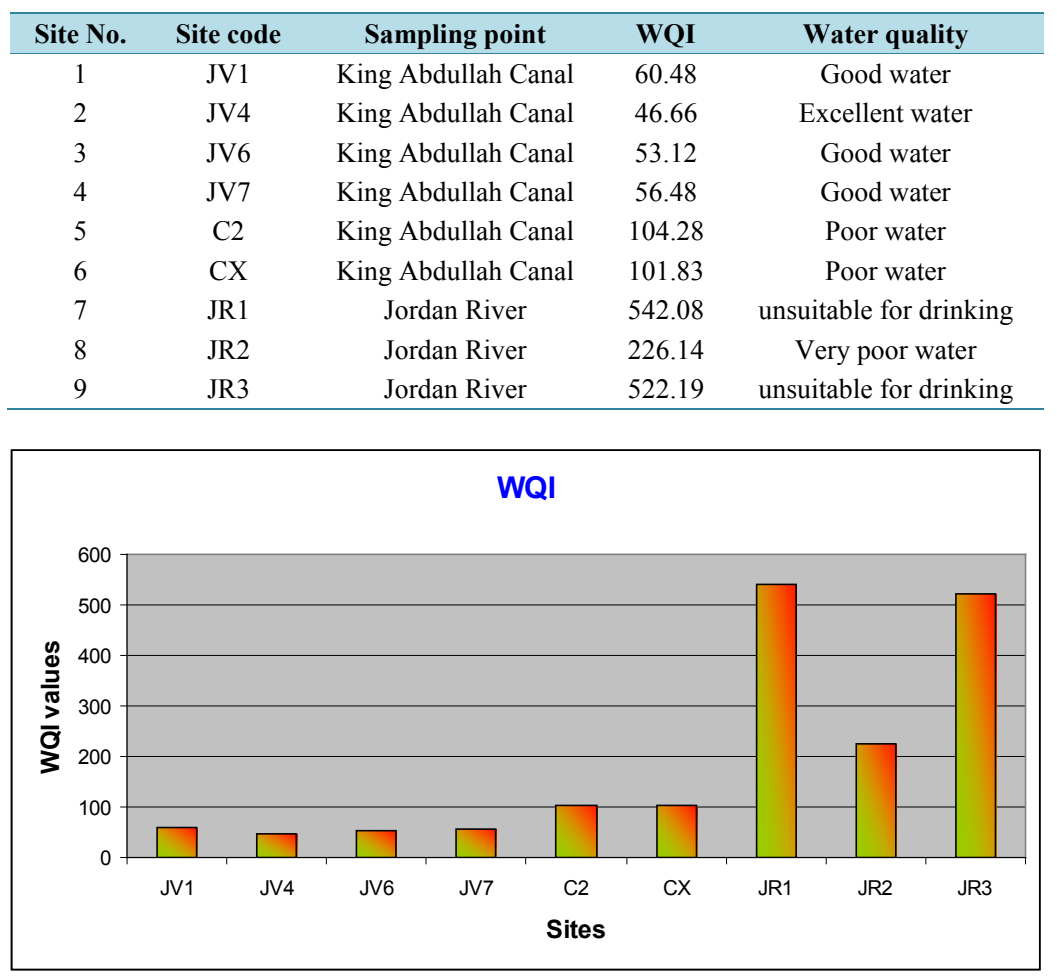

Figure 14. WQI for different water sampling site of the study area. 


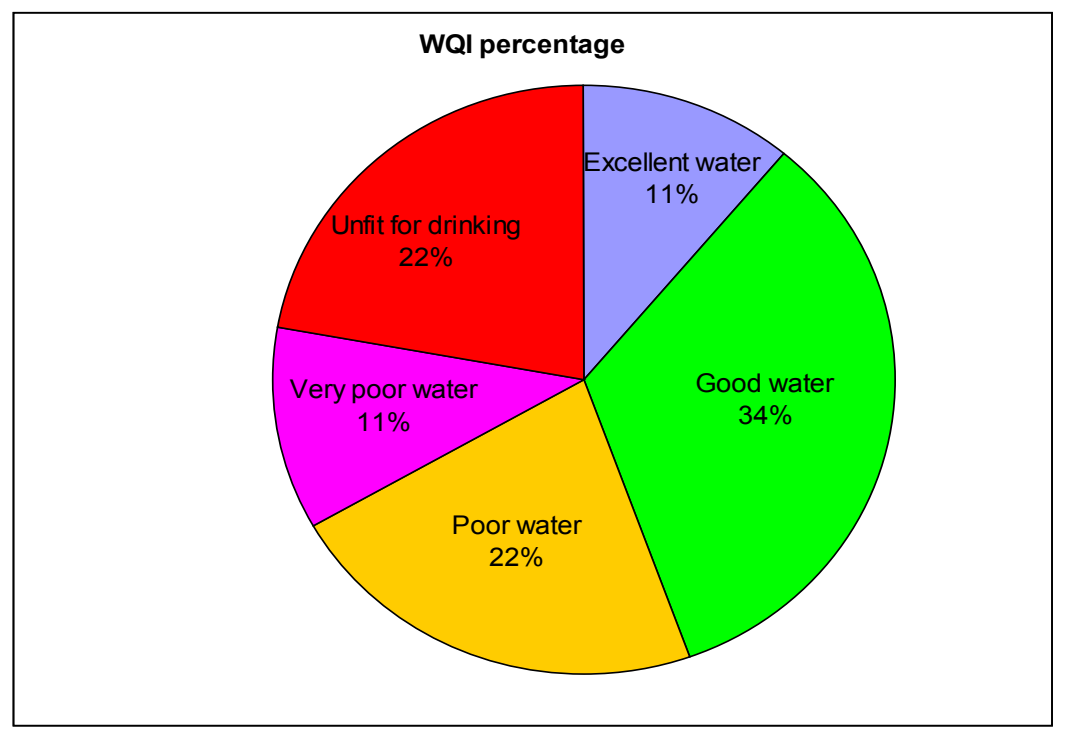

Figure 15. Graphical data representation of WQI classifications.

\section{Conclusions}

Water Quality index (WQI) of the current study for KAC and JR was computed by using nine sampling points from different water parameters in order to evaluate the suitability of water for various purposes. The following conclusions were drawn on the basis of the physico-chemical analysis of surface water for KAC and JR:

1) The computed WQI for nine samples ranged from 46.66 to 542.08 . Almost fifty five percent of the samples exceeded 100, the upper limit for drinking water. The high value of WQI at these sites was found to be mainly from the higher values of sulphate, nitrate, total dissolved solids, chloride, sodium, potassium, magnesium and calcium in the surface water;

2) All the upper part of King Abdullah Canal sites approximately had good water except that sites C2 and CX had WQI values equal to 104.28 and 101.83 respectively;

3) The quality of water at the lower part (sampling sites JR1, JR2 and JR3) was unsuitable or unfit for the human uses $(>300)$. The increased value of WQI at these sites might be due to the mixing with Zarqa River surface water;

4) The analysis found that the water of the canal needed more treatment for human purposes, and it also suggested to be protected from different contaminations;

5) The result from the data analysis showed that the water was certainly not fit for drinking purpose without any form of treatment, but might be considered for other purposes;

6) Comparing with the World Health Organization (WHO) and Jordan Standard (JS), the results indicated that the lower part of the canal was polluted and therefore the water was not safe for domestic purpose and needed some further treatment;

7) The Water Quality Index was a very efficient and useful tool to summarize available data to the decision makers in order to fully understand the type of the water quality and to have a chance for better use in the future as well;

8) The high value of WQI had been found mainly in the lower part of the canal as a result of the mixing of the canal water with the Zarqa River.

\section{References}

[1] Ramakrishnaiah, C.R., Sadashivaiah, C. and Ranganna, G. (2009) Assessment of Water Quality Index for the Groundwater in Tumkur Taluk, Karnataka State, India. E-Journal of Chemistry, 6, 523-530. http://dx.doi.org/10.1155/2009/757424

[2] Okeke, C.O. and Igboanua, A.H. (2003) Characteristics and Quality Assessment of Surface Water and Groundwater Recourses of Akwa Town, Southeast, Nigeria. J. Niger. Assoc. Hydrol. Geol., 14, 71-77.

[3] Tiwari, T.N. and Mishra, M.A. (1985) A Preliminary Assignment of Water Quality Index of Major Indian Rivers. In- 
dian Journal of Environmental Protection, 5, 276-279.

[4] Al-Harahsheh, S.T. (2007) Eutrophication Process along King Abdullah Canal, Chemistry, Organisms, and Resulting Compound. Ph.D. Thesis, University of Jordan, Amman.

[5] Prasada, A.G. and Siddaraju, K. (2012) Application of CCME Water Quality Index (CWQI) to the Lakes of Mandya, Karnataka State. India International Interdisciplinary Research Journal, 2.

[6] Naik, S. and Purohit, K. (1996) Physico-Chemical Analysis of Some Community Ponds of Rourkela. Indian Journal of Environmental Protection, 16, 679-684.

[7] Iwuoha, G. and Osuji, L.C. (2012) Changes in Surface Water Physico-Chemical Parameters Following the Dredging of Otamiri and Nworie Rivers, Imo State of Nigeria. Research Journal of Chemical Science, 2, 7-11.

[8] Sinha, S.K. (1995) Potability of Some Rural Ponds Water at Muzaffarpur (Bihar) - A Note on Water Quality Index. Journal of Pollution Research, 14, 135-140.

[9] Conesa, F. and Vitora, V. (1997) Methodological Guidelines for Environmental Impact Assessment. Mundi Prensa, Bilbao, 338.

[10] Cude, C. (2001) Oregon Water Quality Index: A Tool for Evaluating Water Quality Management Effectiveness. Journal of the American Water Resources Association, 37, 125-137. http://dx.doi.org/10.1111/j.1752-1688.2001.tb05480.x

[11] Gebrehiwot, A.B., Tadesse, N. and Jigar, E. (2011) Application of Water Quality Index to Assess Suitablity of Groundwater Quality for Drinking Purposes in Hantebet Watershed, Tigray, Northern Ethiopia. ISABB Journal of Food and Agriculture Science, 1, 22-30.

[12] Srinivasamoorthy, K., Chidambaram, M., Prasanna, M.V., Vasanthavigar, M., Peter, J. and Anandhan, P. (2008) Identification of Major Sources Controlling Groundwater Chemistry from a Hard Rock Terrain-A Case Study from Metturtaluk, Salem District, Tamilnadu, India. Journal of Earth System Science, 117, 49-58. http://dx.doi.org/10.1007/s12040-008-0012-3

[13] Brown, R.M., McCleiland, N.J., Deininger, R.A. and O’Connor, M.F. (1972) A Water Quality Index-Crossing the Psychological Barrier. Proceedings of the International Conference on Water Pollution Research, Jerusalem, 18-24 June 1972, 787-797.

[14] Tiwari, J.N. and Manzoor, A. (1988) Water Quality Index for Indian Rivers. In: Trivedy, R.K., Ed., Ecology and Pollution of Indian Rivers, Aashish Publishing House, New Delhi, 271-286.

[15] WHO (2004) Guidelines for Drinking Water Quality. 3rd Edition, World Health Organization, Geneva.

[16] WHO (2006) Guidelines for Drinking Water Quality. World Health Organization, Geneva.

[17] Sahu, P. and Sikdar, P.K. (2008) Hydrochemical Framework of the Aquifer in and around East Kolkata Wetlands, West Bengal, India. Environmental Geology, 55, 823-835. http://dx.doi.org/10.1007/s00254-007-1034-x

[18] Ott, W.R. (1978) Environmental Indices: Theory and Practice. Ann Arbor Science Publishers Inc., Ann Arbor.

[19] Pesce, S.F. and Wunderlin, D.A. (2000) Use of Water Quality Indices to Verify the Impact of Córdoba City (Argentina) on Suquía River. Water Research, 34, 2915-2926. http://dx.doi.org/10.1016/S0043-1354(00)00036-1

[20] Ward, R. (2001) Development and Use of Water Quality Criteria and Standards in the United States. Regional Environmental Change, 2, 66-72. http://dx.doi.org/10.1007/s101130100028

[21] Wetzel, R.G. (2001) Limnology: Lake and River Ecosystems. Third Edition, Academic Press, San Diego, 1006 p.

[22] Mumtazuddin, S., Azad, A.K., Bharti, P. and Ranjan, R. (2012) Physico-Chemical Analysis of Groundwater of the Budhi Gandak Belt in Muzaffarpur District, India. International Research Journal of Environment Sciences, 1, 7-11.

[23] Mahvi, A.H. and Razazi, M. (2005) Application of Polyelectrolyte in Turbidity Removal from Surface Water. American Journal of Applied Science, 2, 397-399. http://dx.doi.org/10.3844/ajassp.2005.397.399

[24] Braide, S.A., Izonfuo, W.A.L., Adiukwu, P.U., Chindah, A.C. and Obunwo, C.C. (2004) Water Quality of Miniweja Stream, a Swamp Forest Stream Receiving Non-Point Source Waste Discharges in Eastern Niger Delta, Nigeria. Scientia Africana, 3, 1-8.

[25] Egereonu, U.U. (2004) Assessment of Atmospheric Aerosols from Three Satellite Stations: Heavy Metal Pollutants. Journal of Association for the Advancement of Modelling and Simulation Techniques in Enterprises, 65, 71-88.

[26] Mohanta, B.K. and Patra, A.K. (2000) Studies on the Water Quality Index of River Sanamachhakandana at Keonjhar Garh, Orrisa. Pollution Research, 19, 377-385.

[27] Rajurkar, N.S., Nongbri, B. and Patwardhan, A.M. (2003) Water Quality Status of River Umkhrah at Shillong. International Journal of Environment and Pollution, 23, 990-998. 